$\begin{gathered}\text { EPiC Series in Education Science } \\ \text { Volume 1, 2017, Pages 456-465 }\end{gathered}$
$\begin{gathered}\text { AUBEA 2017: Australasian Universities Build- } \\ \text { ing Education Association Conference 2017 }\end{gathered}$

\title{
Factors Affecting Construction Students' Satisfaction with Grades in Design Courses
}

\author{
Olabode E. Ogunmakinde ${ }^{1}$, William D. Sher ${ }^{1}$, Oladoyin O. Ogunmakinde ${ }^{2}$ \\ and Oluwafemi I. Ayanniyi ${ }^{3}$ \\ ${ }^{1}$ University of Newcastle, New South Wales, Australia \\ ${ }^{2}$ GSM Havilah College, Ibadan, Oyo State, Nigeria \\ ${ }^{3}$ Federal University of Technology Akure, Ondo State, Nigeria. \\ olabode.ogunmakinde@uon.edu.au
}

\begin{abstract}
The construction and built environment sector is dynamic. It is made up of professionals who are knowledgeable about design, planning, construction and cost estimation. Design is one of several courses undertaken by construction students. Assessing design drawings is demanding for tutors as the assessment criteria need careful consideration. Assessment results may encourage or discourage students. Their morale may be affected if they feel their efforts have not been rewarded. Achieving a balance between the tutors' decisions and students' satisfaction is therefore important. This research sought to identify factors affecting students' satisfaction with grades in design courses. The study was undertaken among year 3 and 4 architecture students in a Nigerian university. One hundred and twenty students were invited to reply to an online questionnaire. Their responses revealed that most of them were not satisfied with their tutors. They felt that marking was inconsistent. This study identified a range of ways students felt assessment could be improved. Chief amongst these was a suggestion that the same tutors assessed the work of all students (rather than for several tutors to be involved). Based on these issues, the paper suggests ways to balance tutors' assessments and students' satisfaction.
\end{abstract}

\section{Introduction}

The term "satisfaction" is commonly used when describing the concerns of customers or clients of a product or service particularly in business and marketing industries. Many definitions of satisfaction exist in literature, most of which are from the business and marketing point of view. For example, Oliver 
(1997) described satisfaction as consumers' pleasurable fulfilment that their consumption meets certain goals and desires. Similarly, Fornell (1992) viewed it as the evaluation of a perceived product before and after purchase. High levels of satisfaction of a product or service may be achieved when end users express pleasurable feelings and vice versa. Assessing users' satisfaction of a product or service is a common phenomenon whose results are used to either enhance or change the product. This ideology has been applied in several industries offering products and services including educational institutions.

Universities are responsible for providing education to students. They are service providers, and their students are consumers (Thomas \& Galambos, 2004). To ensure constant growth in a competitive market, it is important that consumers are satisfied with services. Many universities have designed methods to evaluate their performance in terms of service delivery. Students are commonly used data for such evaluation (Pozo-Munoz et al., 2000). Surveys such as interviews and questionnaires e.g. student feedback questionnaire (Coffey \& Gibbs, 2001) are widely used in evaluating students' satisfaction. Others include a Student Rating System (SRS) developed in Kansas State University (IDEA, 2007); Student Instructional Report (SIR) developed by Education Testing Service (ETS, 2006); Student Evaluation of Educational Quality (SEEQ) developed by Marsh (1987, 1991); College Student Satisfaction Questionnaire (CSSQ); Student Course Satisfaction Scale (SCSS) developed by Seoul National University (Byun \& Kim, 2003); and Course Experience Questionnaire (CEQ) developed by Graduate Careers Council of Australia.

\begin{tabular}{lll}
\hline & SEEQ & CSSQ \\
\hline 1 & Learning and value & Policies and procedures \\
2 & Tutor enthusiasm & Working conditions \\
3 & Organisation clarity & Compensation (cost and benefit) \\
4 & Group interaction & Quality of education \\
5 & Individual rapport & Social life \\
6 & Breadth of coverage & Recognition \\
7 & Examinations/grading & \\
8 & Assignments/readings & \\
9 & Workload & \\
\hline
\end{tabular}

Table 1: Categories of students' satisfaction

Similarly, models have been developed and tested to identify and explain factors responsible for students' satisfaction. For example, De Vore and Handal (1981) developed a five-factor model, which comprises working conditions, compensation for cost and benefit, quality of education, social life and recognition. Clemes et al. (2008) also developed a three-factor theory with various sub-factors. It includes interaction quality, outcome quality and physical environment. Several other factors identified in literature includes tutors' direction and support, students' commitment to learning, course factors (Lo, 2010), facilities and resources available (Garcia-Aracil, 2008), quality of education, and social factors (Elliot \& Healy, 2001; Wiers-Jenssen, Stensaker \& Grøgaard, 2002). The CSSQ and SEEQ have been used to measure students' satisfaction in six and nine categories respectively (see Table 1). Other categories and sub categories included students' characteristics: entry qualifications (Ofori, 2000); gender (Tatro, 1995); disability status (Scullion, 2000); ethnicity (Chevannes, 2001) and age (El Ansari \& Oskorochi, 2006). Also included are the course characteristics study mode (Lee et al., 1999); course level (Kerridge \& Matthews, 1998); course module and the qualification aim (Eaton et al., 2000; El Ansari, 2002).

Assessing students' satisfaction helps to identify areas of weakness and strength (El Ansari, 2011). It provides room for improvements and helps administrators focus more on teaching quality (Solinas, Masia, Maida, \&Muresu, 2012; El Ansari, 2002). More so, it will contribute to high educational 
standards through a direct focus on issues of quality development (Wiers-Jenssen, Stensaker, \& Grogaard, 2002). Effective use of the feedback provided by students could improve learning and teaching quality (El Ansari, 2002), allows for course comparisons and improvements (Solinas, Masia, Maida, \& Muresu, 2012) and also highlights students' perceptions of learning and the learning environment created by tutors. Worthy of note by some authors (Umbach and Wawrzynski, 2005; Lo and Olin, 2009a, 2009b; Lo and Prohaska, 2009) is the fact that tutors' roles may be significant in students' satisfaction. They argued that their roles could not be over-emphasised being the course designers whose creativity facilitates students' learning. Therefore, the quality of teaching staff or tutors is a reliable tool in assessing students' satisfaction.

Aside from the quality of teaching, the grades awarded to students by tutors also contributes to students' satisfaction. According to Marsh and Dunkin (1992), attention has now shifted to students' satisfaction with grades obtained at the end of a course. For instance, Pike (1991) examined the relationship between students' grades and satisfaction; he concluded that satisfaction exerted a greater influence on grades than grades do on satisfaction. However, other researchers (Lo and Olin, 2009a, 2009b; Lo and Prohaska, 2009; Umbach and Wawrzynski, 2005) disagreed with Pike's findings. This implies that there are conflicting views about satisfaction and grades. Most studies have focused on the relationship between satisfaction and coursework grades. However, few have examined satisfaction with drawing or design courses and the systems adopted to grade them.

Design is one of several courses undertaken by students in the Architecture, Engineering and Construction (AEC) sector. This sector is made up of professionals who are knowledgeable about design, planning, construction and cost estimation. Many tutors at institutions offering architecture, engineering and construction management have been required or expected to assess students' design drawings. It is demanding for tutors, as the assessment criteria need careful consideration. Assessment results may encourage or discourage students. Some researchers have examined how tutors' assessments influence students' satisfaction. Students may react positively or negatively to the grades awarded them, which could affect learning outcomes. Their morale may be affected if they feel their efforts have not been rewarded. Therefore, achieving a balance between the tutors' decisions (grades) and students' satisfaction is important. Numerous studies on students' satisfaction have been reported but not fully explained (Benjamin and Hollings, 1995; 1997). Most studies focused on satisfaction with grades, style of teaching as well as the infrastructure or facilities provided. However, students' satisfaction with their tutors and the grading systems they adopted have received little attention. This suggests that there is a lot of ground to cover in the area of students' satisfaction. This study therefore sought to discover construction students' level of satisfaction with their tutors based on their scores or grades. The null hypothesis (H0) is that there is no significant difference in construction students' level of satisfaction with their tutors based on their grades. Factors affecting students' satisfaction with grades in design courses were also identified in the study.

\section{Methodology}

This study employed a survey administered within the first semester of the 2016/2017 academic session at the department of Architecture, Federal University of Technology Akure (FUTA), Ondo State, Nigeria. Interestingly, the duration for architecture programmes at the university is five years for a freshman and four years for direct entry. Students enrolled in this programme usually start design courses in year 2 . The study was undertaken among year 3 and 4 students. They were invited to reply to an online questionnaire based on their experiences with their last design course (i.e. Architectural Design - ARC 201 and ARC 301). Students were asked to answer five questions about their satisfaction with grades and the factors that affected them, as well as questions about demographics. The factors affecting students' satisfaction were adapted from literature and grouped empirically. 
Students were asked to respond to the questions on a 5-point Likert scale with the following answers: 1 strongly disagree, 2 disagree, 3 neutral, 4 agree, and 5 strongly agree. The questionnaire included one "open-ended" question aimed at eliciting students' opinion on how design course assessment could be improved. Participants were recruited from the attendance register signed with the design course coordinators. Only those who included their email address in the register were contacted. Overall, 120 students were emailed. The link to the online survey was sent to them with the study's objectives. Participants were made to understand that their consent to participate was implied by submitting the survey and that the survey was voluntary. To do analysis, weighted average of responses (descriptive statistics) and Pearson correlation (inferential statistics) were performed using SPSS version 24.

\section{Findings and Discussion}

For One hundred and two students responded to the survey, which represents $85 \%$ response rate. Two factors could be responsible for the high response rate. One, internet access, which is readily available on most smart phones used by students and two, the survey was student centred. The survey results are presented below:

\subsection{Profile of Respondents}

Table 2 shows students' demographic profiles. $76.5 \%$ are male while $23.5 \%$ are female. This is a fair representation of the actual population of students studying architecture in most universities of technology in Nigeria. The majority of the respondents, $73.5 \%$ were aged between 20 and 24 . The number of year 4 (400 level) students that completed the survey were 54 (52.9\%) while 48 (47.1\%) were year 3 (300 level). This implies that majority of the respondents are experienced having been graded at least twice (i.e. year 2 and year 3) in their design courses. Furthermore, 70.6\% have secondary school educational background; none of the students had technical college educational background while $29.4 \%$ had polytechnic educational background.

\begin{tabular}{lc}
\hline Respondent profiles & Frequency \\
\hline Gender & $78(76.5)$ \\
Male & $24(23.5)$ \\
Female & \\
Age group & $6(5.9)$ \\
$15-19$ & $75(73.5)$ \\
$20-24$ & $21(20.6)$ \\
25 or older & $48(47.1)$ \\
Current level of study & $54(52.9)$ \\
Year 3 (300 level) & \\
Year 4 (400 level) & $72(70.6)$ \\
Educational background & $0(0)$ \\
Secondary school & $30(29.4)$ \\
Technical college & \\
Polytechnic education &
\end{tabular}




\subsection{Actual vs. Expected Score}

The grading system adopted in Nigerian universities is regulated by the National Universities Commission, and are categorised into five namely: A (70 -100), B (60 - 69), C (50 - 59), D (45 - 49) and $\mathrm{F}(0-44)$. Students were asked to provide actual and expected scores in their last design course. None of the students anticipated or received a F. None of them anticipated a D but three (2.9\%) were awarded a D. Only nine (8.8\%) students expected a C but 27 (26.5\%) actually scored a C, 24 (23.5\%) anticipated a B whereas 57 (55.9\%) had it. The majority of the students, $67.6 \%$ anticipated receiving an A grade however, only $14.7 \%$ of them actually had an A. This indicates that students' expectations sometimes do not represent or match their actual performance.

\subsection{Reaction to Design Grade}

Students' reactions to the grades awarded them in their last design course was measured by asking them to respond to a list of possible responses adopted from the literature. Some of the students (35.3\%) felt their efforts had not been rewarded because they did not receive their anticipated or expected grades while $17.6 \%$ were motivated and encouraged. These students could be those whose anticipated grade was their actual grade. Few students (2.9\%) attempted to quit the course as result of low grades, $23.5 \%$ accepted the result and started preparations for the next design course, $14.7 \%$ did not bother about their grade since they did not fail the course while $5.9 \%$ were bothered about their grade but were scared to request a re-mark of their design (see Table 3). The reasons for being apprehensive about asking for a re-mark may have been influenced by factors including student-lecturer relationships, procedures involved, and students' experience.

\begin{tabular}{ll}
\hline Reactions & Frequency (\%) \\
\hline I felt my efforts have not been rewarded & $36(35.3)$ \\
I was motivated and encouraged & $18(17.6)$ \\
I was tempted to quit the course & $3(2.9)$ \\
I accepted the result and started preparations for the next design course & $24(23.5)$ \\
I was not bothered in as much as I didn’t fail & $15(14.7)$ \\
I was bothered but scared to request/call for a re-mark & $6(5.9)$ \\
\hline
\end{tabular}

Table 3: Reactions to grades

\subsection{Factors Affecting Design Grade}

Table 4 shows the factors affecting students' grades in design courses. These have been categorised into three namely: student-based factors, course factors, and tutor-based factors. Student-based factors include their academic background, drawing/design skills and abilities, social life and commitment to learning. The course factors are course contents and requirements while the tutor-based factors are grading system, style of teaching, tutor's instructions, direction and support as well as design studio facilities. The students were asked to rate their level of agreement with statements about the factors on a five point Likert scale with values ranging from 1 to 5 ( 1 = strongly disagree and $5=$ strongly agree $)$. The average weight for each factor was calculated and presented in Table 4. The students were of the opinion that the grading system (3.94) adopted by their tutors was the factor that most probably affecting their grades. This finding is similar to that reported by Umbach and Wawrzynski (2005), Lo and Olin, (2009a, 2009b), Lo and Prohaska (2009) in their studies that tutors play important role in students' satisfaction. Next was the style of teaching (3.82), tutor's instructions, direction and support (3.65), and studio facilities provided (3.59). The factor with the least influence was seen as social life. 


\begin{tabular}{|c|c|c|c|c|c|c|}
\hline & $\begin{array}{l}\text { Strongly } \\
\text { disagree }\end{array}$ & Disagree & Neutral & Agree & $\begin{array}{l}\text { Strongly } \\
\text { agree }\end{array}$ & $\begin{array}{l}\text { Weighted } \\
\text { average }\end{array}$ \\
\hline Academic background & 6 & 45 & 6 & 39 & 6 & 2.94 \\
\hline $\begin{array}{l}\text { Drawing/design skills or } \\
\text { abilities }\end{array}$ & 6 & 18 & 9 & 57 & 12 & 3.50 \\
\hline Social life & 12 & 48 & 21 & 18 & 3 & 2.53 \\
\hline Commitment to learning & 6 & 33 & 18 & 39 & 6 & 3.06 \\
\hline $\begin{array}{l}\text { Course contents and } \\
\text { requirements }\end{array}$ & 3 & 24 & 27 & 45 & 3 & 3.21 \\
\hline Grading system adopted & 6 & 3 & 9 & 57 & 27 & 3.94 \\
\hline Style of teaching & 6 & 0 & 18 & 69 & 9 & 3.82 \\
\hline $\begin{array}{l}\text { Tutor's instructions, } \\
\text { direction, and support }\end{array}$ & 3 & 3 & 30 & 57 & 9 & 3.65 \\
\hline $\begin{array}{l}\text { Design studio's facilities } \\
\text { and amenities }\end{array}$ & 3 & 3 & 42 & 39 & 15 & 3.59 \\
\hline
\end{tabular}

Table 4: Factors affecting design grades

\subsection{Students' Satisfaction}

The students were asked to rate their satisfaction with their performance, course grade, design coordinators and tutors. Design coordinators refer to lecturers in charge of design courses for that semester while tutors are invited panel members to assess designs/drawings at the end of the semester. As shown in Table 5, the students were not very satisfied (2.03) with the tutors but they were somewhat satisfied with their own performance (2.91). It is interesting to note that students were not very satisfied with their tutors perhaps they see them as originators of their low grades rather than learning facilitators. A Pearson correlation was computed to assess construction students' satisfaction with their tutors based on and their grades (expected and actual). There was a positive correlation between the variables, $\mathrm{r}=$ 0.700 (expected score), 0.861 (actual score), $\mathrm{n}=102, \mathrm{p}<0.0001$. Based on this result, the null hypothesis (there is no significant difference in construction students' level of satisfaction with their tutors based on their grades) is rejected. This implies that students are not satisfied with their tutors whenever their expected grade is not the same with their actual grade.

\begin{tabular}{lcccccc}
\hline & $\begin{array}{l}\text { Not at all } \\
\text { satisfied }\end{array}$ & $\begin{array}{l}\text { Not } \\
\text { satisfied }\end{array}$ & $\begin{array}{l}\text { Somewhat } \\
\text { satisfied }\end{array}$ & $\begin{array}{l}\text { Very } \\
\text { satisfied }\end{array}$ & $\begin{array}{l}\text { Extremely } \\
\text { satisfied }\end{array}$ & $\begin{array}{l}\text { Weighted } \\
\text { average }\end{array}$ \\
\hline Course grade & 21 & 45 & 21 & 15 & 0 & 2.29 \\
Performance & 0 & 39 & 33 & 30 & 0 & 2.91 \\
Design coordinators & 3 & 51 & 42 & 6 & 0 & 2.50 \\
Tutors/Jurors & 39 & 33 & 24 & 3 & 3 & 2.03 \\
\hline
\end{tabular}

Table 5: Students’ satisfaction 


\begin{tabular}{llccc}
\hline & & $\begin{array}{c}\text { Students_ } \\
\text { satisfaction }\end{array}$ & $\begin{array}{l}\text { Expected_ } \\
\text { score }\end{array}$ & $\begin{array}{l}\text { Actual_ } \\
\text { score }\end{array}$ \\
\hline Students_ & Pearson Correlation & 1 & $.700^{* *}$ & $.861^{* *}$ \\
satisfaction & Sig. (2-tailed) & & .000 & .000 \\
& $\mathrm{~N}$ & 102 & 102 & 102 \\
Expected_ & Pearson Correlation & $.700^{* *}$ & 1 & $.803^{* *}$ \\
score & Sig. (2-tailed) & .000 & & .000 \\
& $\mathrm{~N}$ & 102 & 102 & 102 \\
Actual_ & Pearson Correlation & $.861^{* *}$ & $.803^{* *}$ & 1 \\
score & Sig. (2-tailed) & .000 & .000 & \\
& $\mathrm{~N}$ & 102 & 102 & 102 \\
\multicolumn{1}{c}{$*$. Correlation is significant at the 0.01 level (2-tailed). } & & \\
\hline
\end{tabular}

Table 6: Pearson correlation

\subsection{Factors Affecting the Grading System}

In order to further understand how the grading system affected their grades, students were asked to rate their level of agreement with the factors affecting the grading system. Table 7 shows their responses. The most highly ranked factor affecting the grading system is different tutors assessing each group of students (4.18). Following this are the tutor's personal approach to design (4.15) and inconsistent marking (4.03). The least ranked factor was students' inability to express themselves during presentations (3.42). Some of the students agreed that their inability to meet submission requirements (3.59) could also be responsible for their low grades while others (3.88) felt that the tutors favoured those who received high grades.

The study sought students' opinions on how to improve tutor's assessment. Via an open-ended question in the questionnaire, students gave several suggestions. These included the use of continuous assessment instead of one-off marking, communicating the grading parameters to all students, allowing more time for students to express their ideas, absolute fairness to all students, and use of a standard assessment scale. Chief amongst these suggestions was that the same tutors assessed the work of all students using the same assessment scale rather than for several tutors to be involved. It is a common practice in most schools of architecture in Nigeria to divide students into groups and assign different tutors to grade each group. This study reveals that students are no longer comfortable with the grading system and hence, there is a need for a review of the system.

\begin{tabular}{lcccccc}
\hline & $\begin{array}{l}\text { Strongly } \\
\text { disagree }\end{array}$ & Disagree & Neutral & Agree & $\begin{array}{c}\text { Strongly } \\
\text { agree }\end{array}$ & $\begin{array}{c}\text { Weighted } \\
\text { average }\end{array}$ \\
\hline $\begin{array}{l}\text { Different tutors assessing } \\
\text { each group of students }\end{array}$ & 6 & 0 & 9 & 42 & 45 & 4.18 \\
$\begin{array}{l}\text { Tutor's personal opinion } \\
\text { or approach to design }\end{array}$ & 3 & 6 & 0 & 57 & 36 & 4.15 \\
$\begin{array}{l}\text { Tutor's inconsistent } \\
\text { markings }\end{array}$ & 3 & 3 & 9 & 60 & 27 & 4.03 \\
\hline
\end{tabular}




\begin{tabular}{lllllll}
\hline $\begin{array}{l}\text { Tutor's personal } \\
\text { impression of the student }\end{array}$ & 3 & 12 & 6 & 57 & 24 & 3.85 \\
$\begin{array}{l}\text { Students' inability to } \\
\text { express themselves (poor }\end{array}$ & 0 & 21 & 27 & 48 & 6 & 3.42 \\
$\begin{array}{l}\text { presentation) } \\
\begin{array}{l}\text { Students' inability to meet } \\
\text { submission requirements }\end{array}\end{array}$ & 0 & 3 & 39 & 57 & 3 & 3.59 \\
Favouritism & 3 & 3 & 15 & 63 & 18 & 3.88 \\
\hline
\end{tabular}

Table 7: Factors affecting the grading system

\section{Conclusion}

This study has assessed the factors affecting students' satisfaction with grades in design courses revealing three categories of factors namely: students-based factors, course factors and tutor-based factors. Student-based factors were further categorised into their academic background, drawing/design skill, commitment to learning and social life. Course factors were categorised based on the course content and requirements while tutor-based factors included the grading system adopted, style of teaching, studio facilities, and tutor's instructions, direction and support. The paper revealed a strong and positive correlation between students' satisfaction with their tutors and grades awarded them. It also identified the grading system adopted as the main factor affecting students' satisfaction with grades. Most students felt their efforts had not been rewarded and because of this, they were not very satisfied with their tutors. However, they were satisfied with their own performance. It was also revealed that different tutors assessing different groups of students affected the consistency with which grading systems were applied. The students suggested that the same tutors assessed the work of all students as a possible way of improving the grading system. The results discussed in this study may not be generalizable to other profession in the AEC sector because only year 3 and 4 architecture students in one university were consulted. This study is significant as it draws the attention of tutors to students' concerns about their grading system. Since students no longer feel comfortable with the grading system, it is recommended that tutors or course coordinators review it and if possible develop an all-inclusive grading system. Future research work may include other students across all levels and universities.

\section{References}

Benjamin, M. \& Hollings, A. (1995). Towards a Theory of Student Satisfaction: An Exploratory Study of the "Quality of Student Life". Journal of College Student Development, 36(6): 574.

Benjamin, M. \& Hollings, A. (1997). Student Satisfaction: Test of an Ecological Model. Journal of College Student Development, 38(3): 213 - 228.

Byun, C. \& Kim, J. (2003). Research for developing student course satisfaction scale in Seoul National University. Seoul National University.

Chevannes, M. (2001). An evaluation of the recruitment of black and minority ethnic students to pre-registration nursing. Nurs. Times Res. 6(2): 626-635.

Clemes, M.D. Gan, C.E.C. \& Kao, T. (2008). University Student Satisfaction: An Empirical Analysis. Journal of Marketing for Higher Education. 17 (2), pp 292-325.

Coffey M., \& Gibbs, G. (2001). The evaluation of the student evaluation of Educational Quality Questionnaire (SEEQ) in the UK higher education. Assess. Eval. High. Educ. 26(1): 89-93.

De Vore, J. R. \& Handal, P. J. (1981). The College Student Satisfaction Questionnaire: A test-Retest Reliability Study. Journal of College Student Personnel, 22, 299-301. 
Eaton, N., Williams, R., \& Green, B. (2000). Degree and diploma student nurse satisfaction levels. Nurs Stand. 14(4): 34-39.

El Ansari, W. \& Oskrochi, R. (2006). What matters most? Predictors of student satisfaction in public health educational courses. Public Health. 120(5): 462-73.

El Ansari, W. (2002). Student nurse satisfaction levels with their courses: Part II - Effects of academic variables. Nurse Educ Today 22(2): 171-180.

El Ansari, W. (2011). Factors associated with students' satisfaction with their educational experiences, and their module grades: Survey findings from the United Kingdom. Educational Research, 2(11) pp. 1637-1647.

Elliott, K.M. \& Healy, M.A. (2001) 'Key factors influencing student satisfaction related to recruitment and retention', Journal of Marketing for Higher Education, 10 (4), 1-11.

ETS (2006). The Student instructional report II: Its development, uses and supporting research. Retrieved April 16, 2017, from http://www.ets.org/

Fornell, C. (1992) 'A national customer satisfaction barometer: The Swedish experience', Journal of Marketing, 56, 6-21.

García-Aracil, A. (2008). “European graduates’ level of satisfaction with higher education.” Higher Education, DOI 10.1007/s10734-008-9121-9.

IDEA (2007). Instructional development and effectiveness assessment student ratings of instruction. Retrieved April 16, 2017, from http://www.idea.ksu.edu

Kerridge, J.B., \& Mathews, B.P. (1998) Student rating of courses in HE: further challenges and opportunities. Assess. Eval. High. Educ. 23: 71-82.

Lee, T., Mawdsley, J.M., \& Rangeley, H. (1999). Students' part-time work: towards an understanding of the implications for nurse education. Nurse Educ. Today. 19: 443-451.

Lo, C. C., and Olin, L. (2009a). Redesigning Courses to Support Active and Collaborative Learning. Paper presented at the Teaching Professor Conference.

Lo, C. C., and Olin, L. (2009b). Shaping and Sharing Active Learning at a Large University. Paper presented at the SoTL Commons Conference, Georgia Southern University.

Lo, C. C., and Prohaska, A. (2009). Environment Conducive to Active and Collaborative Learning: Redesigning Introductory Sociology at a Large Research University. Paper presented at the American Sociological Association Annual Conference.

Lo, C.C. (2010). How student satisfaction factors affect perceived learning. Journal of the Scholarship of Teaching and Learning, 10 (1), pp. $47-54$.

Marsh, H. W. (1987). Student's evaluation of university teaching: Research findings, methodological issues, and directions for future research. International Journal of Educational Research, 11(3), 253-388.

Marsh, H. W. (1991). Multidimensional students' evaluations of teaching effectiveness: A test of alternative higher order structures. Journal of Educational Psychology, 83, 285-296.

Marsh, H.W., Dunkin, M.J. (1992). Students' evaluations of university teaching: a multidimensional perspective. Higher Education: Handbook of Theory and Research (Smart J.C. Ed.). New York: Agathon Press.

Ofori, R. (2000). Age and 'type' of domain specific entry qualifications as predictors of student nurses' performance in biological, social and behavioural sciences in nursing assessments. Nurse Educ. Today. 20: 298-310.

Oliver, C. (1997). Sustainable Competitive Advantage: Combining Institutional and ResourceBased Views. Strategic Management Journal, 18 (9), pp. 697-713.

Pike, G. R. (1991). The Effects of Background, Coursework, and Involvement on Students' Grades and Satisfaction. Research in Higher Education, 32(1): 15.

Pozo-Munoz, C., Rebolloso-Pacheco, E., \& Frenandez-Ramirez, B. (2000). The 'ideal teacher'. Implications for student evaluation on teacher effectiveness. Assess. Eval. High. Educ. 25(3): 253-263. 
Scullion, P. (2000). Disability as an equal opportunity issue within nurse education in the UK. Nurse Educ. Today. 20: 199-206.

Solinas, G., Masia, D., Maida, G. \& Muresu, E. (2012). What Really Affects Student Satisfaction? An Assessment of Quality through a University-Wide Student Survey. Creative Education, 3(1), 37-40.

Tatro, C.N. (1995). Gender effects on student evaluations of faculty. J. Res. Dev. Educ. 28: 169173.

Thomas, E. \& N. Galambos. (2004). "What satisfies students? Mining Student-Opinion Data with Regression and Decision Tree Analysis.” Research in Higher Education, 45 (3) pp 251-269.

Umbach, P. D., and Wawrzynski, M. R. (2005). Faculty do matter: The role of college faculty in student learning and engagement. Resarch in Higher Education, 46(2), pp 153-184.

Wiers-Jenssen, J., Stensaker, B., \& Grøgaard, J. B. (2002). Student satisfaction: towards an empirical deconstruction of the concept. Quality in Higher Education, 8, 183-195. Doi: 10.1080/1353832022000004377. 